\title{
Paranoid schizofreni, paranoide psykoser og personlighetsforstyrrelser
}

\author{
Kjernen i schizofreni er en forstyrrelse i realitetsoppfatningen. Det gir seg utslag i forstyrrelser \\ i sansningene, tankelivet, forholdet til seg selv, til andre mennesker og til dagliglivets aktiviteter.
}

Nå er forstyrrelser i realitetsoppfatningen alminnelig i en rekke mentale forstyrrelser, ja også alminnelig hos folk som neppe vil kvalifisere for en mental diagnose. For å skape en orden i klassifiseringen av hva som er mentale forstyrrelser og hva som ikke er det, og hvilke forstyrrelser det dreier seg om, lager man regler for klassifisering. Dette er særlig viktig i tidlige stadier av en vitenskap, slik som tilfelle er for psykopatologi.

\section{Klassifisering av psykiske lidelser}

Den store revolusjonen i klassifiseringen av mentale forstyrrelser kom med DSM-III (Diagnostic and Statistical Manual of Mental Disorders, 3. ed.) (1). Dette var tredje utgave av USAs eget klassifiseringssystem, som de fikk etter den annen verdenskrig, ettersom de med god grunn var utilfreds med klassifiseringen innenfor ICD (International Classification of Diseases, Classification of Mental and Behavioural Disorders).

DSM-III-klassifikasjonen var bygd opp etter følgende elementer: Inklusjonskriterier; et sett av mer spesifikke kriterier, ofte additive; tidskriterier, kriterier for sosial funksjon og av og til for lidelse; og ikke minst eksklusjonskriterier som fastla et hierarki mellom diagnosene, ved at visse andre diagnoser kunne ekskluderes hvis kravene til en bestemt diagnose var oppfylt. DSM-III ble senere etterfulgt av revisjonen DSM-III-R (2) og DSM-IV (3), og i 2013 kommer DSM-V. I 1993 (4) kom ICD-10 som gjelder for hele verden, og etter DSMV kommer ICD-11, som vil bli mer eller mindre en blåkopi av DSM-V.

Hierarkiet definert gjennom eksklusjonskriteriene er helt essensielt i differensialdiagnostiseringen. Den plasserer schizofreni etter stoffinduserte og organiske psykoser og også (litt uklart) etter affektive (stemningsrelaterte) psykoser, men før paranoide psykoser, akutte psykoser, indusert psykose og personlighetsforstyrrelser.

\section{Vanskelige avgrensninger}

Avgrensningen fra stoffbetingede/organiske psykoser og stemningspsykoser er i prinsippet, om enn ikke i praksis, relativt grei. Jeg skal her i stedet konsentrere meg om den mer komplekse avgrensningen mellom paranoid schizofreni, paranoide psykoser og personlighetsforstyrrelser hvor problemene er større. Avgrensningen er dels basert på symptomenes alvorlighetsgrad og intensitet, dels på tid, hvor lenge de har vart, og dels på kvalitet. Alvorlighetsgrad og intensitet er usikkert å vurdere, varighet av symptomer er lettere, men symptomenes kvalitet er den sikreste indikasjonen på hvilken diagnose som foreligger. Da slipper man problemet med den kontinuerlige dimensjonen fra det alvorlig psykotiske, via lettere psykoser, til personlighetsforstyrrelser, forsvarsmekanismer og alminnelige menneskelige oppfatninger av virkeligheten, seg selv og andre. Hvor disse grensene skal trekkes, kan nemlig fremtre som tilfeldig og opp til det subjektive skjønn - standarder varierer fra kliniker til kliniker.

Hele tiden når man vurderer om en diagnose foreligger, må man ta $\mathrm{i}$ betraktning om væremåten kanskje er i tråd med den kultur man tilhører eller identifiserer seg med. Om tanker og opplevelser er i tråd med den kulturen, dreier det seg ikke om mer og symptomgrupper er alene nok til at diagnosen foreligger.

\section{Tre veier til paranoid schizofreni}

Det går imidlertid an å skjære igjennom og identifisere tre veier til diagnosen paranoid schizofreni:

1) Bisarre vrangforestillinger (som inkluderer påvirkning og kontroll som bryter med naturlovene).

2) Ikke-bisarre, omfattende vrangforestillinger og kommenterende, flere samtalende hørselshallusinasjoner.

3) Ikke-bisarre, omfattende vrangforestillinger, hallusinasjoner av andre typer enn i 2) sammen med tankeforstyrrelser, tilbaketrekking, og eventuelt katatone symptomer som ikke er så uttalte at diagnosene hebefren eller kataton schizofreni foreligger.

«Alvorlighetsgrad og intensitet er usikkert
å vurdere, varighet av symptomer er lettere,
men symptomenes kvalitet er den sikreste
indikasjonen på hvilken diagnose som foreligger»

et symptom på en underliggende forstyrrelse og skal således ikke danne grunnlaget for en mental diagnose. Symptomer er nemlig, ja nettopp, symptomer på at noe vi ikke kan iaktta foreligger. Dette noe skyldes en feilutvikling, genetisk og/eller traumatisk, passiv konsekvens eller aktivt forsvar à la psykoanalytisk tenkning.

Hierarki finnes ikke bare mellom klasser av diagnoser, men også innen en diagnosegruppe. Temaet her er paranoid schizofreni, og da må det påpekes at paranoid schizofreni er plassert lavere i hierarkiet enn kataton og hebefren (disorganisert) schizofreni. For å tilfredsstille kravene til paranoid schizofreni må de generelle kriterier for schizofreni være oppfylt, men kriteriene for kataton og hebefren schizofreni må ikke være fremtredende, slik at man står igjen med kriteriene for schizofreni som dreier seg om paranoide forestillinger. Systemet av kriterier for schizofreni er relativt kronglete, med krav om et minimumsantall symptomgrupper, og et minimumsantall symptomer innen symptomgruppene. Enkelte sympto-
Ad 1): Sentralt i klassifiseringen av paranoid schizofreni står såkalte bisarre vrangforestillinger. Begrepet «bisarr» innenfor dette systemet står ikke for hva man i dagliglivet vil betegne som bisart. Med bisarr mener man noe som er utenfor vårt naturvitenskapelige verdensbilde. Eksempler er at vi har «gjester» fra ekstraterrestrielle verdener i hodet eller hjernen, og blir styrt av dem. Vi kan styre, eller bli styrt gjennom tankeoverføring, kan bli frastjålet eller stjele tanker, deler av kroppen vår råtner bort (ikke-medisinsk), renner vekk. Eksemplene er utallige på slike umulige vrangforestillinger. Men her støter vi på et problem. Sannsynligvis inneholder nesten alle religioner slike bisarre forestillinger, bare tenk på jomfrufødsel, gjenoppstandelse og vandring blant oss, med merker etter spydstikket. Rike amerikanere betaler i dyre dommer for tomter i «Tofu-land» i Arizona fordi visse meridianer går ned der. Seriøse, rasjonelle forretningsfolk i Hongkong sjekker horoskopet før kontrakter underskrives, bygg må reises i pakt med mystiske vinkler og koder 
med mening som ikke reflekteres i vårt naturvitenskapelige verdensbilde. Alt dette er bisart etter definisjonen. Hvorfor det likevel ikke er grunnlaget (alene) for en mental diagnose, er fordi dette er alminnelig tankegods innenfor kulturer og subkulturer. Dermed kan man få disse oppfatningene gjennom enkel, naturlig påvirkning fra andre medlemmer i kulturer. Det er ikke symptomer på en underliggende dysfunksjon, en «maskinfeil», eller en forstyrrelse, forårsaket av nedarvet eller ervervet «skade».

Imidlertid er det en personlighetsforstyrrelse hvor lettere, reelle bisarre vrangforestillinger er relativt vanlig, nemlig schizotyp (personlighets)forstyrrelse. Følgelig er det en utfordring å skille mellom paranoid schizofreni og schizotyp personlighetsforstyrrelse hos en person med bisarre vrangforestillinger. Løsningen er å se på hvor mye vrangforestillingene styrer personen på måter som ødelegger den daglige, alminnelige funksjonsevnen, og hvor fasttømret vrangforestillingene er. Uansett, bisarre vrangforestillinger er en betryggende indikasjon på at paranoid schizofreni foreligger. Men da må man ikke tape av syne at bisart ikke er «science», men «science fiction».

Ad 2). Om ikke bisarre vrangforestillinger forekommer, må man se etter andre vrangforestillinger. Det kan dreie seg om forfølgelse, grandiositet, sjalusi, eller andre typer. (Den norske utgave av ICD-10 inneholder dessverre en oversettelsesfeil hvor «delusion of reference» er blitt oversatt til «selvhenføring». Derved kan man bli ledet feil $i$ et viktig differensialdiagnostisk kriterium, noe som faktisk også har skjedd i en sakkyndig rapport som har vært mye omtalt i det siste) (5). Alle disse formene for vrangforestillinger er vanlig i diagnosen paranoide psykoser. Så hvordan skal man kunne si at det er paranoid schizofreni og ikke paranoid psykose som foreligger? Problemet løses om kommenterende hørselshallusinasjoner foreligger. Man hører stemmer som kommenterer ens person eller hva man gjør, eller man hører noen som snakker sammen. Forekommer ikke slike hallusinasjoner, vil man ende på diagnosen paranoid psykose, eventuelt akutt psykose, alt etter tidsperspektivet. Men det kan også være at det vil være riktig å gå enda et skritt ned i hierarkiet, til paranoid personlighetsforstyrrelse. Dette avhenger av hvor usannsynlige forestillingene er. En gjennomgående skepsis overfor naboer, kolleger, familie, partner, venner, innvandrere, politiske motstandere kan være en del av våre vanlige tankemønstre. Blir det ganske monomant, fanatisk og tar vel mye av oppmerksomheten, går utover ens forhold til menneskene rundt en, kan man tale om en paranoid personlighetsforstyrrelse, så lenge ikke selv meningsfeller begynner å stusse. Da er man over i en paranoid psykose. De med en paranoid personlighetsforstyrrelse kan virke noe selvopptatte. Men om man mener at visse personer er ute etter kongen, statsministeren og meg, eller heller Meg, kongen og tatsministeren, ja da blir en selv så opphøyd at vi har å giøre med en paranoid psykose. Men, notabene, dette er ikke nok til en paranoid schizofreni.

Ad 3). Den tredje veien til diagnosen paranoid schizofreni innebærer ikke-bisarre vrangforestillinger, ikke-kommenterende hallusinasjoner, lettere tankeforstyrrelser og kanskje lettere katatone symptomer. Her er man på tynn is. For tankeforstyrrelsene skal ikke være omfattende, da er det hebefren schizofreni, og klare katatone symptomer må ikke foreligge, kanskje bare litt eksitasjon. Ellers blir det kataton schizofreni. Så hvor lette skal disse symptomene være? Her møter man igjen paranoid psykose som alternativ diagnose, og også paranoid personlighetsforstyrrelse. Men fremfor noe møter man diagnosen schizotyp personlighetsforstyrrelse som inneholder alle elementer av vrangforestillinger og lettere tankeforstyrrelser. En person med flere av følgene væremåter: lettere paranoide forestillinger, magisk tenkning, underlig, omstendelig og oppstyltet måte å kommunisere på (lager gjerne konstruerte ord som enkelte feilaktig kan betegne som «neologismer»), lite mimikk, affekter, med avgrenset sosial kontakt og aggressive fantasier, kanskje veksling mellom litt passivitet og litt overaktivering, lettere, tidsavgrensede hallusinasjoner - bør sannsynligvis få diagnosen schizotyp personlighetsforstyrrelse.

\section{Oppsummering}

Oppsummerende kan man si at om klare katatone symptomer foreligger (sjelden i vår tid), peker det mot schizofreni. Det samme er tilfelle med omfattende tankeforstyrrelser. I begge tilfeller vil det sosiale fungering være svært dårlig. Det tredje symptommønsteret som peker mot schizofreni er omfattende bisarre vrangforestillinger (inkludert ekstrasanselig påvirkning og kontroll). Det fjerde dreier seg om massive hallusinasjoner, gjerne i flere modaliteter inkluderende lukt, og kommanderende og kommenterende hørselshallusinasjoner. Er ikke noe av dette til stede, vil en schizofrenidiagnose være svært usikker. Alternative diagnoser vil være paranoide psykoser og personlighetsforstyrrelser, først og fremst paranoide og schizotype. Uten bisarre vrangforestillinger eller omfattende/kroppslige hallusinasjoner vil diagnosen måtte bli paranoid psykose, om realitetsbristen er stor nok, og ikke schizofreni.

Et kompliserende element er at selv tanker som ville måtte betegnes som bisarre om man bare så på det formelle tankeinnholdet, er et integrert element av enhver kultur. Formelt sett temmelig massive paranoide vrangforestillinger finnes innenfor politiske subkulturer. Derfor er det ikke en lett oppgave å avgrense hva som er en forstyrrelse.
Terskelen er såpass lav for å anvende betegnelsen personlighetsforstyrrelse at risikoen for å gjøre feil innenfor denne diagnosegruppen neppe er så stor. Men går man opp til paranoid psykose, blir det verre. Da skal personen skille seg ut fra kulturen eller subkulturen, bli oppfattet som «rar» (så sant ikke diagnosen indusert psykose «folie à deux»)) blir anvendt. Schizofreni, også paranoid schizofreni, krever virkelig et nytt sprang i psykopatologisk endring. Selv om den sosiale fungering kan være så noenlunde, er en aktiv pågående paranoid schizofreni noe som står frem som et massivt avvik fra det vanlige. Ser man på seg selv som en Kristus-skikkelse, en stor hærfører à la Djengis Khan eller en middelaldertids munk, kan man være paranoid psykotisk, ha en paranoid personlighetsforstyrrelse eller bare være en svermer. Men tror man at man faktisk er en av disse, kan det kvalifisere for en paranoid schizofreni, sammen med andre kriterier. For så lenge er ikke et menneske i stand til å leve.

\section{Svenn Torgersen}

svenn.torgersen@psykologi.uio.no

Regionsenter for barn og ungdoms psykiske helse, $\emptyset$ st og Sør

Svenn Torgersen (f. 1941) er professor emeritus i klinisk psykologi, Universitetet i Oslo og for tiden ansatt som forsker I ved Regionsenter for barn og ungdoms psykiske helse, Øst og Sør. Forfatter har fylt ut ICMJE-skjemaet og oppgir ingen interessekonflikter.

\section{Litteratur}

1. APA. Diagnostic and Statistical Manual of Mental Disorders. Third Edition (DSM-III). Washington, D.C.: American Psychiatric Association, 1980.

2. APA. Diagnostic and Statistical Manual of Mental Disorders. Third Edition Revised(DSM-III-R). Washington, D.C.: American Psychiatric Association, 1987.

3. APA. Diagnostic and Statistical Manual of Mental Disorders. Fourth Edition (DSM-IV). Washington, D.C.: American Psychiatric Association, 1994.

4. The ICD-10 Classification of Mental and Behaviour Disorders. Genève: World Health Organization, 1993.

5. ICD-10. Psykiske og atferdsforstyrrelser. Oslo: Gyldendal Akademisk (Statens helsetilsyn), 1999.

Mottatt 7.3. 2012 og godkjent 8.3. 2012. Medisinsk redaktør Erlend Hem. 